\title{
BUSINESS RISK IN TIMES OF ECONOMIC RECESSION AND ECONOMIC GROWTH
}

\author{
JAKUB HORÁK, ${ }^{\mathrm{a}}$ PAVEL DLOUHÝ \\ ${ }^{a, b}$ Institute of Technology and Business in České Budějovice, \\ School of Expertness and Valuation, Okružní 517/10, 37001 \\ České Budějovice, Czech Republic \\ email: ${ }^{a}$ horak@mail.vstecb.cz, ${ }^{b} 27365 @ m a i l . v s t e c b . c z$
}

Abstract: The issue of business risk in times of recession or growth is very topical in these times. The Czech Republic and its neighboring countries are currently struggling with the economic problems caused by the Covid-19 pandemic. The aim of the paper is to analyze the number of insolvency petitions in the Czech Republic from the years 2010-2020 and to compare them with each other. The data source are data from publicly available resources from the Creditreform group and also from the CRIF database of the Cribis platform. First were created tables for the Agriculture and Forestry, Manufacturing, Construction and Transport sectors. Data for the relevant years were added to them from the aforementioned resources. Then was created a line chart for each industry. Using time series analysis and comparison, we analyze and compare the development of insolvencies. At the same time, we use causal analysis to find out why there were high numbers of insolvencies in the given years. We are also looking at which sectors were hit hardest during the insolvency crisis, when they were hit hardest, how they did in times of economic growth and how they should adapt to the next possible crisis. During the Great Recession, the construction sector was hit the hardest, and then the Ding the Great Recession, the construction sector was hit the hardest, and then the transport sector also suffered greatly. The largest numbers of insolvencies can be observed in 2012. At a time of economic growth, which began in 2014, the numbers of insolvencies fell in all sectors analyzed, but mostly in agriculture and forestry and transport. Businesses in the sectors analyzed can adapt to the next crisis by creating larger cash reserves or changing, for example, crop production or transport by temporarily reducing fares to attract new customers. We see the benefit of this work in the analysis of the number of insolvencies in the given sectors, which has not been recorded in almost any academic papers. We also see a benefit in determining the conditions for how companies can prevent another crisis.

Keywords: business risk, insolvencies, time series, agriculture and forestry, manufacturing, construction, transport

\section{Introduction}

The economy of any country in the world goes through periods of prosperity and growth. At other times, a phase of recession comes. The Czech Republic was affected, either to a lesser or greater degree, by the crisis in 2008, which is also called the Great Recession. This economic crisis was considered an internal global labor market shock (Moritz, Stockinger and Trepesch, 2017). On the other side, according to some economists have more qualified professions more resilience against recession's pressure (Svoboda and Applová, 2016) According to statistics, European unemployment did not manifest itself until the so-called post-recession, namely after 2010. The Czech Republic struggled with this crisis until 2014. However, the Great Recession began in the United States in the real estate market, when in the southern part of the United States real estate prices rose by $170 \%$. This situation was called the real estate price bubble and it gradually "burst". With the growth of interest rates, clients began to fall into trouble when repaying mortgage loans (Musílek, 2008).

The latest financial crisis is ongoing throughout the whole world at this very moment, at the time of the Covid 19 pandemic. Restrictions in various sectors are affecting and will further affect production, services and unemployment. On the other hand, the pandemic will help the gradual transition to Industry 4.0. For example, by using technologies that, thanks to human face recognition, will help to reduce contact when checking in at airports, also help to improve school teaching via the Internet and make automate production (Bhardwaj et al. 2021; Ludbrook et al. 2019). But what these aforementioned crises, and other previous ones, certainly have in common, are insolvencies and subsequent bankruptcies of companies and firms. It is the bankruptcy of companies with related insolvency proceedings, as the impact of the economic crisis on companies that seems to be a very topical issue due to the economic crisis arising as a result of the coronavirus situation. Insolvency proceedings are defined as the inability of companies to cover their debts, in other words liabilities. It can take place in two different ways: either by reorganization or liquidation (Smrčka, Schönfeld and Čámská, 2018). This also raises the need for experts to address this issue and find a parallel between the impact of the crisis on businesses in the 2008 crisis and the economic crisis of 2020.
As has already been stated, the economic crisis in the form of the Covidu-19 pandemic is now affecting a significant percentage of businesses and will undoubtedly result in the bankruptcy of many of them. One possible way for businesses to avoid the effects of this pandemic is to adapt to this situation. Businesses face the challenge of finding solutions to ensure their viability and remain sound. Another aid to alleviate the crisis may be the payment of financial support to entrepreneurs who are forced to shut down their businesses due to the pandemic. At the beginning of the epidemic, the government approved a one-time aid of twenty-five thousand CZK to these entrepreneurs (Andoh, 2020). In addition, other financial aids are paid, whether for gastronomy, transport or culture.

The aim of this work is to analyze the number of corporate insolvencies in times of economic recession or economic growth. Furthermore, which fields were most affected by the crisis and which year was the worst in the number of insolvencies and for what reason. Finally, a plan will be set out on how to adapt to the current situation or to a possible further crisis. The goal stems from an analysis of data on the number of insolvent companies in times of economic growth and times of economic recession over the years, specifically from 2010 to 2020.

\section{Literature Research}

Insolvency proceedings are governed by Act No. 186/2006 Collection, on bankruptcy and the manner of its proceedings, otherwise referred to as the Insolvency Act. It can be solved in a total of four ways, namely bankruptcy, reorganization, debt relief or other ways of resolving bankruptcy. The main goal is transparency, overall acceleration and streamlining of the management process, as well as strengthening the position of creditors (Svobodová, 2013). According to Svobodová (2013), insolvency in the Czech Republic is a daily problem of a large number of people. She is of the opinion that the worsening of the situation regarding the insolvency of companies and individuals was mainly due to the economic crisis and low financial literacy. The analysis, focused on the comparison of data on filed insolvency proceedings, confirmed that their number has been gradually growing since 2008. Her analysis deliberately focused on data from 2008, as data from earlier years were not available.

Čámská (2020) focused on the insolvency of companies and firms from the point of view of their capital structure, how the capital structure can influence insolvency proceedings. Data from the Albertina corporate database were used for the research. The financial structure of the insolvent company was recorded on 1,700 pieces of data. In addition, about one hundred thousand observations were made. These focused on solvent companies from all sectors. The data were analyzed using relative and absolute frequencies, which monitored the use of debt and certain capital resources accompanied by a leveraged financial ratio. The analysis showed that insolvent companies were $40 \%$ more indebted than solvent companies, some were even over-indebted.

On the contrary, Smrčka, Schönfeld and Ševčík (2012) pondered how to adjust the insolvency law. The analysis of the functioning of the Insolvency Act and other attached regulations in the years 2008 to 2012 shows that insolvency proceedings are usually initiated at a later stage, when the insolvent company already owns only a very small amount of assets that are not sufficient to satisfy the company's liabilities. Smrčka, Schönfeld and Ševčík (2012) came to the conclusion that comprehensive changes in the insolvency law are needed. At the same time, they present specific changes in the law that would help improve this unsustainable situation.

The number of insolvency proceedings in the Czech Republic was affected by the crisis in 2008, also known as the Great Recession. This could be compared to the Great Depression of 
the early 1930s, as they both have their common origins in the United States. But they also had other similarities and similar factors (Lungová, 2011; Dias, Alexandre and Heliodoro, 2020). Both crises began due to the turbulence in financial markets, which led to a decline in industrial production and world trade. Lungová (2011) divided the factors into short-term and longterm. Among the short-term ones she included a relaxed monetary policy - i.e., lower interest rates. This has helped lowincome people invest in real estate. This created a real estate bubble, which subsequently burst and created significant problems for financial institutions. This crisis was responsible for the collapse of the American bank Lehman Brothers in September 2008, an institution almost 156 years old (ČTK, 2018). Long-term factors that affected the economic crisis in 2008 included, for example, unregulated financial market management, imbalances in savings and investment with rising oil prices. The analysis revealed that the mentioned factors had an impact on the crisis in 2008 (Lungová, 2011).

Research from the Czech Statistical Office (hereinafter referred to as the CZSO) focused on the situation during the crisis in 2008. According to the CZSO (2011), the Czech Republic withstood the crisis relatively well. It was an imported crisis caused by a decline in foreign demand. The fall in GDP between 2009 and 2008 did not differ much from the European Union average. The employment market lost about $1.2 \%$ of people. Compared to the European Union, it was lower than average. However, Pošta and Hudeček (2017) add that the labor market in the Czech Republic was only affected after a long time, when the Great Recession began to manifest itself for the first time. Pissarides (2013) also commented on this issue, using the Beveredge curve to analyze unemployment in the United Kingdom, the USA, Germany and OECD member states (Organization for Economic Co-operation and Development). The United States was the worst out of the unemployment analysis. Wages and salaries in the Czech Republic decreased by $5 \%$. As for consumer prices, they rose sharply in 2008 due to global causes. The increase was mostly reflected in food prices (CZSO, 2011). Tvrz and Vašíček (2016) commented on the structural changes in the Czech, Slovak and Euro-EU economies during the crisis in 2008. To study structural changes, they used nonlinear dynamic stochastic models of general equilibrium with time-varying parameters. The parameters of the model were estimated using the Bayesian method and a nonlinear particle filter. There were similarities between the Czech and Slovak economies. In addition, they add that the Czech economy was more similar to the euro area economy during the crisis. Thus, they came to the same conclusion as the CZSO statistics.

Ball (2014) observed the Great Recession from a broader perspective. He examined the effects of the crisis on OECD member countries, including the Czech Republic. By measuring the potential product in comparison with the established estimates, Ball (2014) revealed significant differences in changes in production in different countries. A significant decrease in the volume of production was recorded, for example, in Australia or Switzerland. In contrast, in Greece or Hungary, potential output fell by almost $30 \%$. The average loss of all OECD member countries was $8.4 \%$.

The world is currently going through an economic crisis caused by the Covid-19 pandemic. At the financial markets many investors diversity their portfolios (Rommer, Majerová and Machová, 2020; Pardal et al. 2020). Ahmad et al. (2020) focused on the initial situation in China. They claimed that China's gross domestic product would fall to $5.6 \%$. At the beginning of the pandemic, restaurants, cinemas, churches, mosques and shops were closed. These businesses, or rather their operators, received financial aid to compensate for their lost profits. Chen et al. (2020) analyzed the effects of this pandemic in Europe and the United States using high-frequency indicators. Their research documented the fact that the greater the outbreak in a given country, the greater the economic impact and losses that resulted. Weekly energy consumption in all thirty-two European countries was used for the analysis. Despite lower prices in the spring months, energy consumption in the countries declined. Out of all of them, however, consumption fell the most in Italy, which had one of the largest outbreaks of Coronavirus in Europe.

Ambriško et al. (2020) debated the specific effects of the pandemic in the Czech Republic. In March 2020, the Czech Republic took similar measures as China and other European countries. Ambriško et al. (2020) predicted a decline in economic activity and from the expenditure components of GDP the impact on household consumption, investment and exports. However, the Czech government has tried and is still trying to mitigate the consequences of the measures taken through various compensation programs, such as the so-called Antivirus. Furthermore, the development of inflation components was expected - an increase in food prices due to higher transport prices and a lack of seasonal employees. On the other hand, the development of service prices and the decline in fuel prices will reduce inflation.

Mesároš (2020) focused on the positive impact of the Covid-19 pandemic in the area of trade, specifically on the company Respilon, based in Brno. It is one of the world leaders in the production of face masks from nanofibers. Here, the demand has increased compared to other fields. At the same time, online mobile banking at ČSOB began to be used to a greater extent, the use of which increased by up to $35 \%$ year-on-year (Patria Finance, 2020). But the company that was largely affected by the pandemic is Czech Airlines (ČSA). At the suggestion of the company itself, the court sent it into insolvency proceedings, because it owes its creditors around 1.8 billion CZK. ČSA saw in the submission of this proposal the possibility of reorganizing and rescuing the company (Zendulka, 2021).

The first suitable method for dealing with business risk is document analysis and then time series analysis. We will then compare the data using comparison. Ball (2014) used the same method to compare potential product estimates. The next method for addressing business risk is causal analysis. By analyzing the number of insolvencies in industries in the Czech Republic during different time periods, we will look for the year when the number of insolvencies was the highest and for what reason. Chen et al. (2020) used this causal analysis to prove that the larger the focus in a given country, the greater the economic impacts that country faced. This was demonstrated by lower energy consumption in Italy at a time when the Covid-19 pandemic was escalating in the country.

\section{Data and methods}

We will use document analysis to collect data. The base research data will be obtained from three sources. The first data source for the number of insolvency petitions from 2010 to 2017 will come from publicly available sources found on the Google search engine, which used data from the Creditreform group. We will primarily use the tables Insolvency by industry. For each industry, we will create a separate table in Microsoft Excel with two columns and fourteen rows. The first column will contain the years and the second the number of insolvencies. Specifically for the manufacturing industry, it is necessary to sum up data from the paper industry, chemical industry and production from plastics, food industry, woodworking, engineering, production of glass, ceramics, building materials, metals, furniture, printing services and repair and installation of machines.

The second source will be data from the Cribis database from the CRIF platform. The data are divided into four groups of industries according to the CZ-NACE classification and are again recorded in a Microsoft Excel document. We will primarily work with a filter in column D called Active. We will choose to select inactive businesses. Next, we will gradually work with the filter for column E, named DateOfLiquidation. We will gradually filter out the dates from 2018, 2019 and 2020, because these are data that we are missing in the tables for these years. When done, the number of filtered businesses based on our criteria, such as the number of inactive businesses in 2017, will appear in the page layout bar. We divide this number by five, because each business is listed five times in the table. This 
will give us the actual number of inactive businesses for that year.

The third source for us will be the website kurzy.cz. Here we will use data for the year-on-year development of the Czech Republic's GDP in percentages. We will rewrite the data from the graph into a table with the same dimensions as for the number of insolvencies.

After editing the data in Microsoft Excel, we will have the data for each sector written in four tables. For the possibility of applying our method, i.e. time series analysis, following the analysis of documents, we will create a line graph for each industry using a function in Excel. Each of these graphs captures the number of insolvencies from 2010 to 2020. Once created, we can analyze the development of insolvency petitions for the sectors. At this stage, thanks to the analysis of time series, we will come to the conclusion which sectors were most significantly affected during the crisis. At the same time, in this phase we will use the method of comparison, where we compare the created graphs and data, in which year there were the most insolvency petitions and also a causal analysis, when we determine the reason why the highest number of insolvencies was in that particular year.

We will also use a table showing the year-on-year development of GDP expressed as a percentage. Again, we will use the graphing function in Microsoft Excel to create a line graph. Capturing developments will help us to compare with data on insolvencies in individual sectors. Thanks to the comparison, we will be able to assess which sector was successful in times of economic growth.

\section{Results}

The first figure below shows the number of filed insolvency petitions recorded in a graph relating to agriculture and forestry. The numbers of insolvency petitions shown by the line graph are linked to the years 2010 to 2020 . We are thus monitoring the beginning of the Great Recession and its impact on insolvency. In the chart we can observe a linear growth of insolvency petitions from 2010 to 2012. From 2013, the numbers began to gradually decline. From 2015 to 2019, the end of our analysis, the number of petitions remained at relatively same values. Since 2020, at a time when we are experiencing another crisis due to the Coronavirus pandemic, it is interesting that the increase in the number of insolvencies in this sector has not been noticeable.

Figure 1: Number of insolvency petitions in 2010-2020 in the field of agriculture and forestry

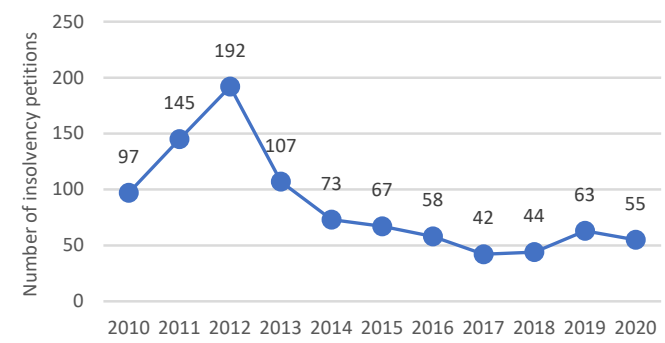

Year

Source: Own processing based on Cribis dataset.

The second figure shows the number of filed insolvency petitions in the field of manufacturing, which can include the production of food, furniture or textiles. As in the case of agriculture and forestry, we are seeing the same growth trend in insolvency petitions. The numbers grew more moderately in 2010 and 2011. A sharp increase can be seen between 2011 and 2012. On the contrary, in 2013 and 2014 the numbers started to decrease significantly and later the decreases were more modest. However, we do not observe continuity at the end of the analysis in the number of insolvency petitions as in the previous graph. In 2020, the number of insolvencies in this sector increases.

Figure 2: Number of insolvency petitions in 2010-2020 in the manufacturing industry

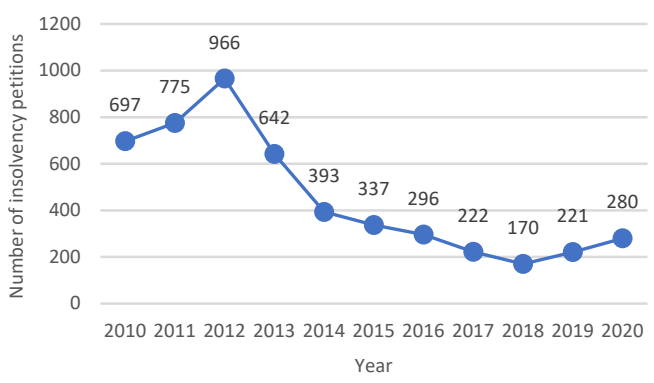

Source: Own processing based on Cribis dataset.

The third figure shows the development of the number of insolvencies in construction. Here, too, we see the same development trend as in the previous charts. From 2010 to 2012, we can see another increase in insolvency petitions, which again peaked in 2012. After that, we record a decline, the most significant overall between 2013 and 2014. The decrease in petitions lasts until 2018, from 2019 there has been a slight increase again.

Figure 3 Number of insolvency petitions in 2010-2020 in the field of construction

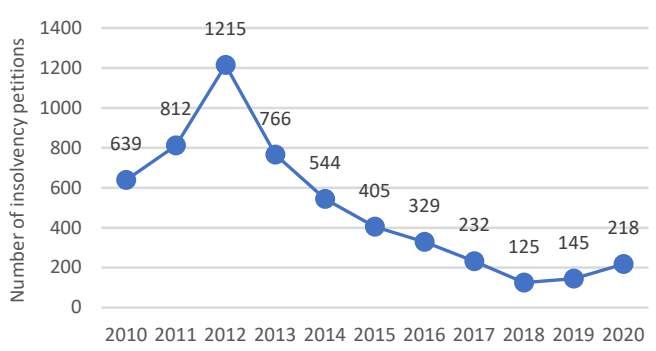

Year

Source: Own processing based on Cribis dataset.

In the graph located in the fourth figure, we deal with the number of insolvency petitions in transport. Here we can observe fluctuations between 2010 and 2011, when the number of insolvency petitions in 2011 is lower than in 2010. We record the highest increase in 2012, as in previous sectors. Then, over the years, we notice an almost linear decline in insolvency until 2018. From 2019, there is again a small increase in the number of petitions.

Figure 4: Number of insolvency petitions in 2010-2020 in the field of transport

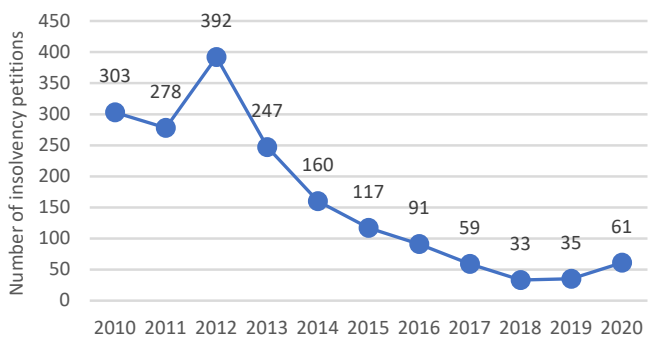

Year

Source: Own processing based on Cribis dataset. 
In the last figure, we capture the year-on-year development of the Czech Republic's GDP since 2008. This will help us determine which sector was the most prominent in terms of the number of insolvencies in the period of economic growth. economy prospered, albeit with slight fluctuations. A large yearon-year decline in GDP occurred in 2020.

Figure 5: Graph of the year-on-year development of the Czech Republic's GDP in percentages

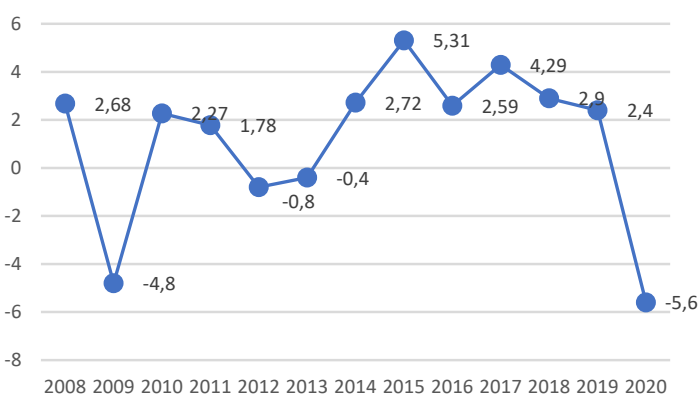

Source: Own processing based on datasets from www.kurzy.cz.

The chart shows the year-on-year decline of GDP in 2009 compared to 2008, when the crisis began in the United States in autumn. Another decline comes in 2012 and 2013. In the following years, the Czech

\section{Discussion}

With the help of time series analysis, we found out the development of the number of insolvency petitions in the field of Agriculture and Forestry, Manufacturing, Construction and Transport in the Czech Republic for the years 2010 to 2020. The same course of development took place in these four named sectors. Since the beginning of the analysis, i.e. 2010, we have observed an increase in the number of filed insolvency petitions, which lasts until 2012. In the sectors of agriculture and forestry, these numbers are growing almost linearly, while in the manufacturing and construction industries the increase is smaller between 2010 and 2011 compared to 2011 and 2012. In the case of transport, the number of insolvency petitions even decreased in 2011, compared to 2010 .

The year 2012 is certainly interesting. In 2012, the highest number of filed insolvency petitions was recorded in all analyzed sectors. This may be due to the euro area crisis in 2011 and 2012. This is also likely to match GDP developments in those years in Figure 5, when there were year-on-year declines in output. Urbánek (2012) demonstrates these problems in the lower growth of companies in the first half of 2012, which was then the lowest in the last five years. At the same time, he mentions the economic problems of the time, such as the restriction of lending by banks, thus the attempts by companies to try to cut costs as much as possible, as well as tax hikes or deteriorating payment morale of companies. Problems in construction are captured in the Analysis of the Development of the Czech Economy in 2012 (2013), prepared by the Ministry of Industry and Trade, specifically by Department 31400. This confirms the decline in construction output by $6.5 \%$.

From 2013 onwards, we can observe a decline in the number of insolvencies. It is also possible to see from the graph of GDP development that there has been a gradual increase from this year on and thus an increase in economic growth. According to the then Prime Minister of the Czech Republic Bohuslav Sobotka, the crisis in the Czech Republic also occurred due to inappropriate government policy, which failed to set a strategic plan for the economy (Urbánek, 2014). The undesirable economic situation also affected the construction industry. Later, the state of the Czech economy and at the same time the construction industry improved.
The increase occurs in 2020, when the aforementioned global coronavirus pandemic. Apart from agriculture and forestry, we see increases in insolvency petitions in all sectors analyzed. Despite the large economic downturn, the increases are not as high as they might seem. The reason, in our opinion, is the payment of compensatory aid, which still keep companies running. However, the development in the following years may not be completely favorable, especially when these bonuses cease to be paid out.

According to the data from the graphs, we can clearly determine that the construction sector was the one most affected by the crisis. In 2012, as mentioned above, the Czech economy was in recession. This is further evidenced by the graph of annual GDP growth. The construction industry suffered greatly due to this economic situation. Furthermore, in terms of the number of insolvencies, the manufacturing industry was also affected. However, it includes a number of other areas and thus a large number of companies, so from this point of view this sector has not been affected so heavily. On the other hand, transport also suffered significantly in the crisis, where we also record a large number of insolvency petitions.

We can observe economic growth from approximately 2014 to 2019. However, the decline in insolvencies began as early as 2013. The low number of insolvency petitions was quickly achieved by the agriculture and forestry and transport sectors. At the same time, we are seeing a decline in the construction industry, but not as sharp as in the above-mentioned sectors. On the contrary, we register a large decline in the manufacturing industry between 2012 and 2014. Which then, however, slowed down significantly.

This is very difficult, because both the crisis in 2008 and the current one are, in a way, specific. As we mentioned earlier, during the 2008 crisis, the construction industry was hit hard by the economy in recession. In today's crisis, the fields of hospitality and gastronomy, as well as retail, are suffering the most. The only advice we would give to owners of businesses to overcome another possible crisis is to have a sufficient financial reserve. It is not possible to make so many recommendations for the sectors we have analyzed - what comes to mind is, for example, changing production in the processing industry, growing crops that are in short supply. In transport, such as bus travel, we would propose a fare reduction to attract more new passengers, even at the cost of lower revenues, and then a reincrease in price. We think the most important aspect is to have a sufficient money reserve and also enough material reserves. The financial support paid by the government can also be of some help. But it cannot be paid out forever.

\section{Conclusion}

The aim of this work was to analyze the number of insolvency petitions during the economic recession and economic growth and to find out which sectors were the most affected in what year, and how the sectors performed during the economic growth. The aim was also to find out which year was the worst for the sector in terms of the number of insolvencies. Using document analysis, time series analysis, comparison methods and also causal analysis, we came to conclusions for these questions.

During the writing of this work, we encountered several complications. One of them was the lack of data on the number of insolvency petitions for the individual sectors. The data could be found in publicly available sources but was only available for some years. For the following years, the data were provided to us from the CRIF database. Another complication for us was the lack of documents focusing on the same topic as this work, from which it would be possible to carry out literature research or simply determine the method of research.

In our opinion, this paper has a high potential for further continuation. The Czech Republic and the world are now in the crisis of the Coronavirus pandemic. It is obvious that the Czech 
economy is in a deep recession. So far, it has not manifested itself much in terms of the number of insolvencies. After the end of compensation programs for entrepreneurs, we can expect an increase in the number of corporate insolvencies and bankruptcies, but these were not the topic of this work. Therefore, this paper would have the potential for further analysis of the number of insolvency petitions and mapping of their further development.

\section{Literature:}

1. Ahmad, T., Haroon, H., Baig, M., Hui, J.: Coronavirus disease 2019 (COVID-19) pandemic and economic impact. Pakistan Journal of Medical Sciences. 2020, 36. ISSN 1681-715X.

2. Andoh, R.: The impact of COVID-19 on global economy: the case of the Czech Republic. International Journal of Multidisciplinary Sciences and Advanced Technology. 2020, 1(2), 22-29 p. ISSN 2708-0587.

3. Ball, L.: Long-term damage from the Great Recession in OECD countries. European Journal of Economics and Economic Policies: Intervention. 2014, 11(2), 149-160 p. ISSN 20527764. 4. Bhardwaj, V., Agarwal, P., Nayak, S. R., Sisodiya, M. S., Singh, V.: Usance of industrial 4.0 technique to overcome the pandemic situation of COVID-19. IOP Conference Series: Materials Science and Engineering. 2021, 1017(1). ISSN 1757899X.

5. Č́mská, D.: Capital structure of insolvent companies in the Czech Republic. International Advances in Economic Research. 2020, 26(3), 319-320 p. ISSN 1083-0898.

6. Chen, S., Igan, D., Pierri, N., Presbitero, A.: Tracking the economic impact of COVID-19 and mitigation policies in Europe and the United States. IMF Working Papers. 2020, 20(125). ISSN 1018-5941.

7. ČTK, 2018. Krize $\mathrm{v}$ datech: kudy vedla cesta $\mathrm{k}$ pádu Lehman Brothers a recesi [Crisis in the data: where the path led to the collapse of Lehman Brothers and the recession]. Česká televize [Czech Television]. Available at: https://ct24.ceska televize.cz/ekonomika/2586556-krize-v-datech-kudy-vedlacesta-k-padu-lehman-brothers-a-recesi

8. CZSO, 2011. Dopady světové finanční a hospodářské krize na ekonomiku ČR [Impacts of the global financial and economic crisis on the Czech economy]. Czech statistical Office [online]. Available at: https://www.czso.cz/documents/10180/20534938/ 115610j.pdf/b487dd3c-0ad7-4ccd-b62d-8fc9bf917b95?versio $\mathrm{n}=1.0$

9. Diaz, R., Alexandre, P., Heliodoro, P.: Contagion in the LAC financial markets: the impact of stock crises of 2008 and 2010. Littera Scripta. 2020, 13(1), 32-45 p. ISSN 1805-9112.

10. Ludbrook, F., Michalíková, K. F., Musová, Z., Šuleř, P.: Business models for sustainable innovation in Industry 4.0: smart manufacturing processes, digitalization of production systems, and data-driven decision making. Journal of SelfGovernance and Management Economics. 2019, 7(3), 21-26 p. ISSN 2329-4175.

11. Lungová, M.: Economic crisis 2008-2009: analysis of its causes. E \& M Ekonomie a Management. 2011, 14(2), 22-30 p. ISSN 1212-3609.

12. Mesároš, J.: Koronavirus jako byznys př́ležitost [Coronavirus as a business opportunity]. Kurzy.cz: Aktuálně [Topically]. 2020. Available at: https://www.kurzy.cz/z pravy/531371-koronavirus-jako-byznys-prilezitost/

13. Moritz, M., Stockinger, B., Trepesch, M.: Multinational resilience or dispensable jobs? German FDI and employment in the Czech Republic Around the Great Recession. Prague Economic Papers. 2017, 26(3), 345-359 p. ISSN 1210-0455.

14. Musílek, P.: Causes of global financial crises and regulation-failure. Český finanční a účetní časopis [Czech financial and accounting magazine]. 2008, 4, 6-20 p. ISSN $1802-2200$

15. ODBOR [Department] 31400. Analýza vývoje ekonomiky ČR za rok 2012 [Analysis of the development of the Czech economy in 2012]. Ministerstvo prümyslu a obchodu [Ministry of Industry and Trade of Czech Republic]. 2013. Available at: https://www.mpo.cz/assets/dokumenty/48686/54874/601806/pril oha001.pdf
16. Pardal, P., Dias, R., Šuleř, P., Teixeira, N., Krulický, T.: Integration in Central European capital markets in the context of the global COVID-19 pandemic. Equilibrium-Quarterly Journal of Economics and Economic Policy. 2020, 15(4), 627-650 p. ISSN 1689-765X.

17. PATRIA FINANCE, 2020. ČSOB v době pandemie: zrychlení trendu digitalizace, růst úvěrů i vkladů, odklady splátek klientům [ČSOB during the pandemic: acceleration of the digitalization trend, growth of loans and deposits, deferrals of repayments to clients]. Kurzy.cz: Investice [Investment]. Available at: https:/www.kurzy.cz/zpravy/566414-csob-v-dobepandemie-zrychleni-trendu-digitalizace-rust-uveru-i-vkladuodklady-splatek-klientum/

18. Pissarides, Ch. A.: Unemployment in the great recession. Economica. 2013, 80(319), 385-403 p. ISSN 00130427.

19. Pošta, V., Hudeček, T.: Features of the regional labor markets in the Czech Republic. Statistika-Statistics and Economy Journal. 2017, 97(2), 36-69 p. ISSN 0322-788X.

20. Rommer, D., Majerová, J., Machová, V.: Repeated COVID19 pandemic-related media consumption: minimizing sharing of nonsensical misinformation through health literacy and critical thinking. Linguistic and Philosophical Investigations. 2020, 19, 107-113 p. ISSN 1841-2394.

21. Smrčka, L., Schönfeld, J., Č́mská, D.: Large insolvency proceedings in the Czech Republic - general characteristics. International Advances in Economic Research. 2018, 24(3), 297-298 p. ISSN 1083-0898.

22. Smrčka, L., Schönfeld, J., Ševčík, P.: The possibilities of reforming Czech insolvency law. WSEAS Transactions on Business and Economics. 2012, 10(3), 190-200 p. ISSN 11099526

23. Svoboda, O., Applová, P.: Determinants of employment and GDP resilience in the context of an economic crisis: evidence from EU countries and regions. Littera Scripta. 2016, 9(2), 140155 p. ISSN $1805-9112$.

24. Svobodová, L.: Vývoj insolvenčního řízení v České republice [Development of insolvency proceedings in the Czech Republic]. Ekonomika a management. 2013, 1(11).

25. Tvrz, S., Vašíček, O.: Structural changes in the Czech, Slovak and euro area economies during the Great Recession. Review of Economic Perspectives. 2016, 16(4), 297336 p. ISSN 1804-1663.

26. Urbánek, V.: ČEKIA: V Česku vzniká nejméně firem za posledních pět let [The Czech Republic has had the fewest companies in the last five years]. Kurzy.cz: Podnikání [Business]. 2012. Available at: https://www.kurzy.cz/zpravy/33 6527-cekia-v-cesku-vznika-nejmene-firem-za-poslednich-petlet/

27. Urbánek, V.: Rok 2014 bude pro české stavebnictví i ekonomiku rokem hospodářského obratu [2014 will be a year of economic turnover for the Czech construction industry and the economy]. Kurzy.cz: Investice [Investment]. 2014. Available at: https://www.kurzy.cz/zpravy/366867-rok-2014-bude-pro-ceskestavebnictvi-i-ekonomiku-rokem-hospodarskeho-obratu/

28. Zendulka, J.: Soud dnes poslal C̆SA do insolvence, majitelé letenek by měli zbystřit [The court sent CSA into insolvency today, ticket holders should sharpen]. Kurzy.cz: Finance. 2021. Available at: https://www.kurzy.cz/zpravy/583153-soud-dnesposlal-csa-do-insolvence-majitele-letenek-by-meli-zbystrit/

\section{Primary Paper Section: A}

Secondary Paper Section: $\mathrm{AH}$ 